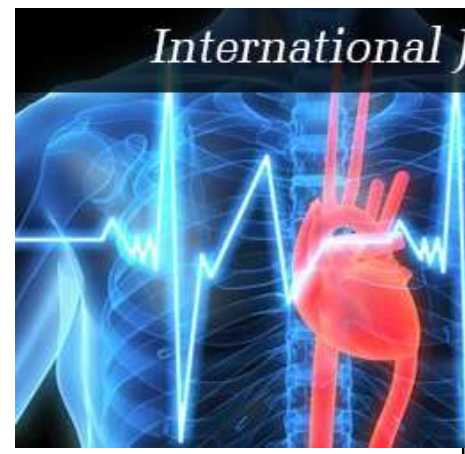

ISSN: $2456-0057$

IJPNPE 2021; 6(1): 71-75

(C) 2021 IJPNPE

www.journalofsports.com

Received: 17-11-2020

Accepted: 02-01-2021

Francisco Javier Gil-Espinosa Researching in Sport Sciences (RSS) Research Group,

Department of Body Expression, Faculty of Science Education, University of Malaga, Andalusiatech, IBIMA, Malaga, Spain

\section{Corresponding Author:}

Francisco Javier Gil-Espinosa Researching in Sport Sciences (RSS) Research Group, Department of Body Expression, Faculty of Science Education, University of Malaga, Andalusiatech, IBIMA, Malaga, Spain

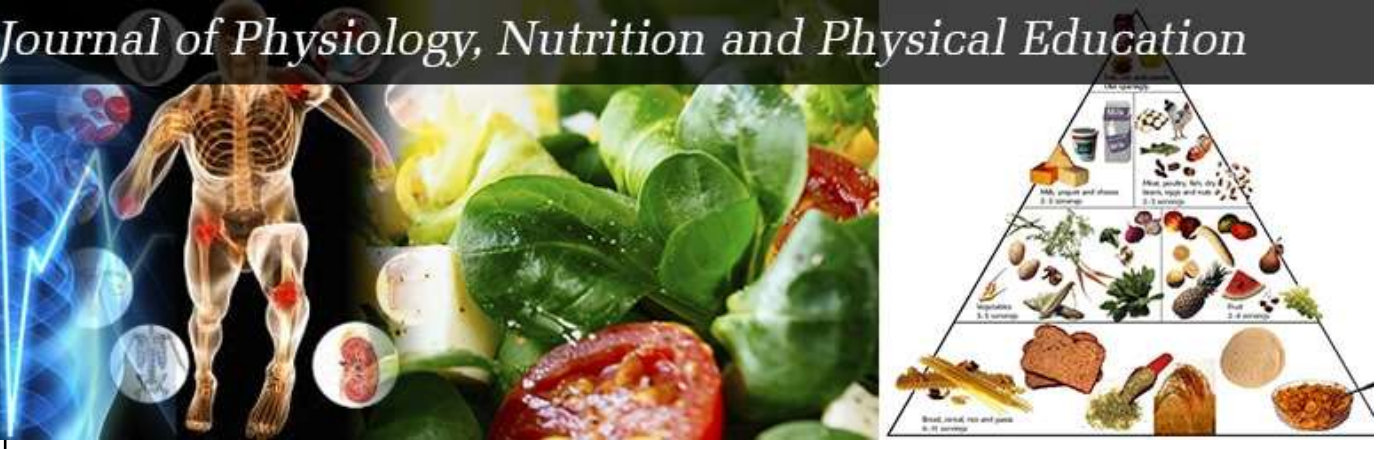

\title{
Physical education and conflict resolution
}

\section{Francisco Javier Gil-Espinosa}

\author{
DOI: https://doi.org/10.22271/journalofsport.2021.v6.i1b.2165
}

\begin{abstract}
Secondary schools are a reflection of the society that surrounds them, therefore, conflicts and the techniques for their prevention and resolution must be considered by the teachers. The purpose of this research is to identify variables related to conflict resolution of the physical education (PE) teachers in relation to school coexistence in compulsory secondary education. The participants are 147 instructors of (PE) who are teaching actively in institutions of compulsory secondary education. Participants completed two questionnaires created 'ad hoc' to evaluate the students' problematic behaviors regarding coexistence in these classes. A description was made of the characteristics of the teaching staff and their schools, for which the absolute and relative frequencies were described in the qualitative variables and the mean values and standard deviation were calculated for the quantitative variables. The results of this research provide guidance for the use of different variables of conflict resolution and teacher mediation in secondary schools. The use of conflict resolution techniques by physical education teachers and educational centers could help improve the atmosphere of coexistence and reduce the number of conflictive incidents.
\end{abstract}

Keywords: Compulsory secondary education, teachers, coexistence, school

\section{Introduction}

Faced with coexistence conflicts, teachers are in a fairly conservative position (Bardisa, 2007a; García 2007) ${ }^{[1,2,6,7]}$ they highlight that, by following the postulates of so-called academic teaching instead of adopting an ethical and transformative approach. There are prejudices such as attributing individual pathologies of biological, psychological or social origin to violent students, and accepting that violence is inherent to human nature and, therefore, inevitable, with which the demands of teachers are reduced, requesting solutions designed by others. Thus, Bardisa (2007b) ${ }^{[1,2]}$ highlights as generic difficulties the tendency to individualize the problem as if it were not related to the professional work of the teachers, the isolated work of the teaching staff, not considering the positive coexistence in the school projects as a priority issue, lacking of an adequate understanding of the profession in postgraduate courses.

García (2005) and Bardisa (2007a) ${ }^{[1,2,6,7]}$ find a manifestation of different interests, even opposing ones, among teachers belonging to different bodies. It was considered that the professional objectives of the teaching staff of the Secondary Education body should be different from those of the teaching staff that came from the Primary Education body, although both performed their tasks as teachers in the same institute. However, they consider that it is unfair to speak of a lack of responsibility in the teacher as an element that explains the maladjustment of the school apparatus. It would be fair to put shared responsibility first.

The current school is a complex society, where there is great heterogeneity (Radajell, 2002 and Bardisa, 2007a) ${ }^{[1,2]}$, constituting educational phenomena as highly complex, citing many variables simultaneously and interactively (Rincón, 2002; Fernández, 2007; García, 2007) ${ }^{[4-7 \text {, }}$ 12, 13, 16].

Much of the "hidden curriculum" understood as the set of processes that run under the educational control that teachers carry out in a conscious and planned way, is formed by communication systems, the forms that power acquires in all senses and coexistence styles that take place in the school institution (Ortega, 2007) ${ }^{[12]}$.

Palomero and Fernández $(2002)^{[4,5,12,13,16]}$ and Estévez $(2005)^{[3]}$ point out that the profiles of school violence are the same as violence in general, presenting four large spheres of activity, microsystem, mesosystem, ecosystem and macrosystem. Solana (2003 and 2005) ${ }^{[18,19]}$ 
indicates that an increase in the type of students with participation problems has been observed in PE classes, so that teaching professionals should use the appropriate methodological strategies to improve the involvement of students in the classrooms, fostering interaction between them and the teacher. At the same time, it asks about the didactic strategies used to achieve development objectives of values, attitudes, conducts and behaviors, as well as about the organizational strategy.

For this reason, they justify that school violence or programs to promote and/or improve coexistence in educational schools cannot be addressed in a unidimensional way, or by resorting to recipes or patches, but rather requires a systemic, ecological, interdisciplinary and pluricausal, promoting effective changes in the social context rather than trying to directly modify the behavior of the individual.

The present research tries to know variables related to conflict resolution of the PE teachers in relation to school coexistence. It is framed in the Educational Research Project with reference PIV-069/08, funded by the Junta de Andalucía and complements other publications.

\section{Materials and Methods}

The research design was based on a population-based crosssectional study through the application of questionnaires addressed to Physical Education (PE) teachers who teach ESO levels in public schools in the Autonomous Community of Andalusia.

The inclusion criteria of the participants were two: 1 . To be an active PE teacher during the 2007/2008 academic year in a public school that teaches the ESO stage in Andalusia. 2. Have completed, at least, the basic data of the first questionnaire (so that the analysis of the study variables was possible) and completely the second questionnaire (which deals with the measures applied before the appearance of disruptive behaviors in class).

\section{Sample}

The population under study are professors from the PE area who work in Andalusian public schools. Out of a total of 844 schools, 147 questionnaires were received from 110 different schools, of which 82 questionnaires were from 59 schools from localities with three or more schools, 46 questionnaires from 38 schools in the provincial capitals, and 19 questionnaires from 13 schools from localities with one or two schools.

The sample size was 147 subjects, which for the supposed simple random sample (MAS), and of maximum indeterminacy $\mathrm{p}=\mathrm{q}=50 \%$, and for a confidence level of $95 \%$ it supposes a maximum sampling error of $+/-8 \%$. We must point out the sample size as a limitation of the study that does not allow the results to be generalized but does not alter the results of the study, given the nature of its objectives.

Taking into account the above criteria, Table 1 shows the number of schools to which the questionnaires were sent by post, distributed by province. They add up to a total of 471 shipments, about 844 schools.

\section{Data collection instrument: Questionnaires}

The instruments used were two questionnaires specifically designed for this purpose. Questionnaire 1 called "Strategies used by the school and the Physical Education teacher in relation to Coexistence (EUCEFC)" provides data on the participants for the present study. Questionnaire 2 called "Measures taken against Behaviors contrary to coexistence and Participation in Physical Education class (MA3CPEF)" collects the most frequent measures and contemplates the option of introducing a new one by the respondents. The data in this publication correspond to questionnaire 1 .

The elaboration of these questionnaires began with a bibliographic review in search of the conditioning factors of coexistence in educational schools as well as similar investigations, after which an initial proposal was prepared to be reviewed by seven experts, representative people for their training and profession in relation to school coexistence, two university professors of Education Sciences, a university professor of Physical Activity and Sports Sciences, a Doctor and Inspector of Education, a Doctor and Counselor of Secondary Education, a Director of the School of teacher training and a teacher of Secondary Education of Physical Education. The questionnaires were redesigned with the improvements proposed by the group of experts before proceeding to the last phase, applied to fellow professors and ESO teachers, as a pilot study. Finally, the results of the pilot study were analyzed in order to finalize the writing of the data collection instruments, and the final questionnaires were obtained.

\section{Data collection procedure}

The questionnaires were sent to each of the public schools in Andalusian towns with three or more ESO schools by post, to the attention of the P.E. Department, including a stamped envelope and with the return data filled in for their return, along with the cover letter.

The rest of the schools, in localities with one or two ESO schools, were sent by email, giving the option of answering in electronic file, in an application designed "online" or by printing the questionnaires or requesting them, to your shipment by post.

A week after the questionnaires were sent, an email was sent to the schools, for the attention of the P.E. Department, presenting and informing them of their sending. After sending the e-mail, some of the members of the PE Department of the schools were contacted by telephone who had not confirmed receipt or sent a response.

\section{Statistic analysis}

A description was made of the characteristics of the teaching staff and their school, for which the absolute and relative frequencies were described in the qualitative variables and the mean values and the standard deviation (SD) were calculated for the quantitative ones.

The data were recorded and processed through the statistical program "Statistical Package for Social Science" (SPSS) version 15.0.

\section{Results and Discussion Sample}

Table 1 reflects the data corresponding to the teachers participating in the study, out of a total of 147 subjects and questionnaires, 101 male teachers $(68.71 \%)$ and 46 female teachers $(31.29 \%)$ participated, with an average, of 13,71years seniority in the faculty, and an average age of 40.03 years. 
Table 1: Sample data in relation to the characteristics of the participating teachers

\begin{tabular}{|c|c|c|c|}
\hline \multicolumn{2}{|l|}{ Sample personal data } & $\mathbf{n}$ & \%/Average (D.T.) \\
\hline Age & Average (D.T.) & 147 & $40,03(9,59)$ \\
\hline \multirow{2}{*}{ Sex } & Man & 101 & 68,71 \\
\hline & Woman & 46 & 31,29 \\
\hline Teach $1^{\circ}$ ESO & Yes & 96 & 65,31 \\
\hline Teach $2^{\circ}$ ESO & Yes & 94 & 63,95 \\
\hline Teach $3^{\circ}$ ESO & Yes & 82 & 55,78 \\
\hline Teach $4^{\circ}$ ESO & Yes & 90 & 61,22 \\
\hline Experience as teacher (years) & Average (D.T.) & 147 & $13,71(8,95)$ \\
\hline Experience in the school (years) & Average (D.T.) & 147 & $7,29(6,72)$ \\
\hline Students' ratio $1^{\circ} \mathrm{ESO}$ & Average (D.T.) & 96 & $26,47(4,68)$ \\
\hline Students' ratio $2^{\circ} \mathrm{ESO}$ & Average (D.T.) & 94 & $25,79(4,72)$ \\
\hline Students' ratio $3^{\circ} \mathrm{ESO}$ & Average (D.T.) & 82 & $26,32(4,87)$ \\
\hline Students' ratio $4^{\circ}$ ESO & Average (D.T.) & 90 & $26,73(4,19)$ \\
\hline Do you hold or have you held a managerial position? & Yes & 46 & 31,29 \\
\hline How many teachers teach PE in the school? & Average (D.T.) & 147 & $2,88(1,91)$ \\
\hline
\end{tabular}

\section{Prevention and treatment of conflicts}

Table 2 shows the results of the fifth dimension, relative to the prevention and treatment of conflicts.

Table 2: Results regarding the prevention and treatment of conflicts

\begin{tabular}{|c|c|c|c|}
\hline \multicolumn{2}{|l|}{ Results regarding the prevention and treatment of conflicts } & $\mathbf{n}$ & $\%$ \\
\hline \multirow{5}{*}{ Do you pay special attention to peer abuse? } & Never & 0 & $0,0 \%$ \\
\hline & Ever & 7 & $4,9 \%$ \\
\hline & Many times & 41 & $28,5 \%$ \\
\hline & Always & 93 & $64,6 \%$ \\
\hline & Don't Know & 3 & $2,1 \%$ \\
\hline \multirow{5}{*}{$\begin{array}{c}\text { Is a School Agenda necessarily used (in the school) as a means of planning and exchanging } \\
\text { information between parents and teachers? }\end{array}$} & Never & 27 & $18,8 \%$ \\
\hline & Ever & 20 & $13,9 \%$ \\
\hline & Many times & 25 & $17,4 \%$ \\
\hline & Always & 66 & $45,8 \%$ \\
\hline & Don't Know & 6 & $4,2 \%$ \\
\hline \multirow{5}{*}{$\begin{array}{c}\text { Do you solve problems at low levels (privately, quietly, near the student, before or after } \\
\text { class)? }\end{array}$} & Never & 1 & $0,7 \%$ \\
\hline & Ever & 29 & $20,1 \%$ \\
\hline & Many times & 74 & $51,4 \%$ \\
\hline & Always & 38 & $26,4 \%$ \\
\hline & Don't Know & 2 & $1,4 \%$ \\
\hline \multirow{5}{*}{ In case of losing general control of the class, are you forced to raise your voice loudly? } & Never & 18 & $12,5 \%$ \\
\hline & Ever & 74 & $51,4 \%$ \\
\hline & Many times & 32 & $22,2 \%$ \\
\hline & Always & 12 & $8,3 \%$ \\
\hline & Don't Know & 8 & $5,6 \%$ \\
\hline \multirow{5}{*}{ Do you address problems as soon as possible? } & Never & 0 & $0,0 \%$ \\
\hline & Ever & 0 & $0,0 \%$ \\
\hline & Many times & 37 & $25,7 \%$ \\
\hline & Always & 104 & $72,2 \%$ \\
\hline & Don't Know & 3 & $2,1 \%$ \\
\hline
\end{tabular}

93.1\% affirm that they pay special attention to abuse among peers "quite a few times" or "always", 77.8\% that they solve problems at low levels and $97.9 \%$ that they address problems as soon as possible. possible.

Figure 1 shows the data corresponding to the use of group conflict resolution techniques and whether the conflict mediator teacher is consulted (in the 57 cases that figure exists in the school). $29.9 \%$ answered that "many times" or "always" they use conflict resolution techniques and $21 \%$ that they go to the mediator teacher. 


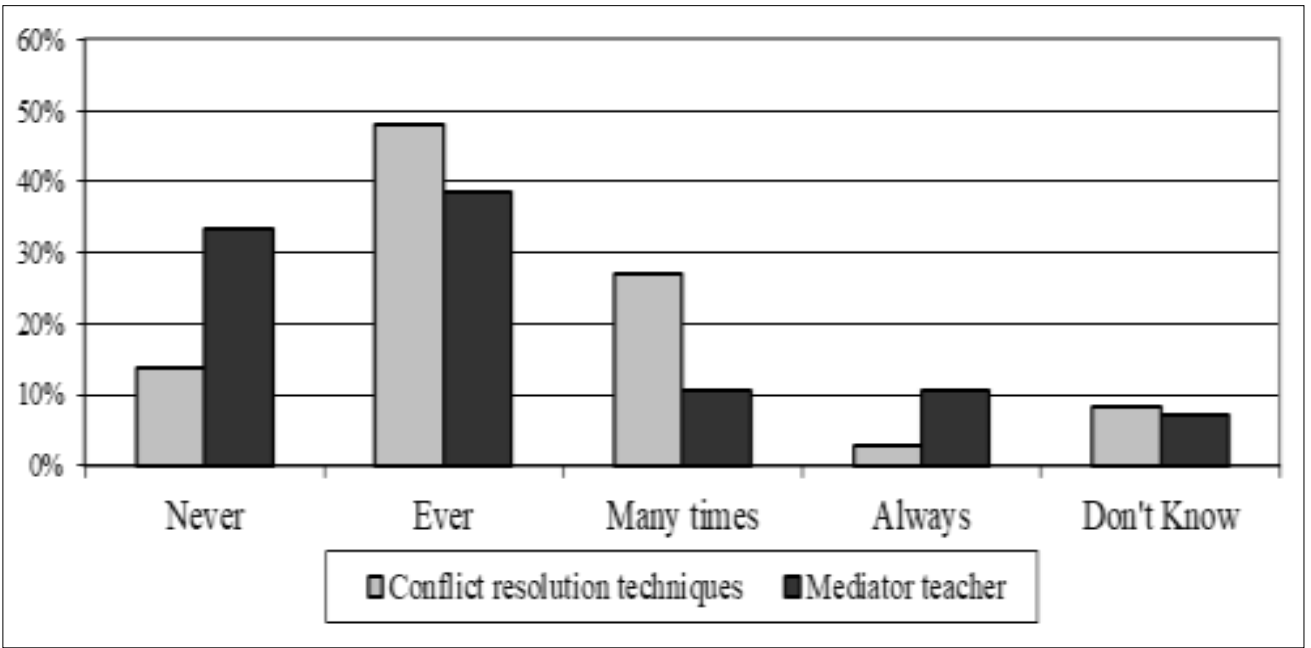

Fig 1: Data corresponding to the use of group conflict resolution techniques and whether the conflict mediator teacher is consulted

Jares (2006) ${ }^{[8]}$ points out that there is little research in our country on conflict and coexistence in Education, and in general, it focuses only on violence between equals. The causes of the problem are often attributed to the media, the social crisis of the moment, family situations, the educational system since the period of compulsory schooling increased or the teachers themselves who express with anguish that they lack the resources to handle the problem. indiscipline of the students (Moliner and Martí, 2002) ${ }^{[11]}$. Little, Henrich, Jones and Hawley (2003b) ${ }^{[9]}$ talk about multidimensional factors as the cause of aggressiveness in general. Martínez-Otero (2001) ${ }^{[10]}$ indicates that school violence is due to a set of factors (multiple causes), highlighting the increase in schooling, the influence of the media, the reflection of a society with high doses of violence.

Fernández-Balboa (1991) $[4,5,12,13,16]$ tells us about the complexity in classroom management, motivated by factors such as: (1) many actions occur simultaneously, (2) students have the ability to hide their bad behavior and (3) novice teachers lacks assertiveness and managerial skills.

Prat and Soler (2002) ${ }^{[14]}$ find in the application of their work to improve coexistence through play, physical activity and sport, in primary schools, that approaching it from the whole of the educational school generates many difficulties for its organization, especially in those schools where it is not possible to create a teamwork dynamic among the teaching staff. At the same time, they highlight how each school integrates the proposal in a very different way, highlighting very different work dynamics depending on the different schools and the different educational contexts.

Rodríguez et al. (2004) ${ }^{[17]}$ conclude that the actions of the Administration, both with regard to teachers and schools, seem to be far from being adequate, inasmuch as the school settings currently do not have a true training policy, both for professionals teaching as that of parents and students, at the same time that there is no influence on catalyzing possible community resources or favoring personal initiatives and those of each school. Faced with this, the present time leads to proposals and measures of a drastic nature in accordance with the social alarm that is provoked, that is, expulsions from the school, the classroom, rejection, isolation... in front of those who promote and induce coexistence and prosocial cooperation. In turn, they affirm that there is no realistic policy aimed at developing the possibilities of the schools and the minimum preventive/corrective programs to confront violent behavior in schools outside of the specific positioning of the discipline.
Thus Villar (1993), cited by Moreno et al. (2007), in relation to the teacher's contribution to the promotion of disciplined behaviors in PE class, defends that an adequate teaching attitude reduces discipline problems, allows group control and gives the teacher more time for correction and feedback to students, increasing their participation and effectiveness in the classroom, and consequently learning. In the same way, Wuest (1998) [21] is pronounced, considering discipline problems as a challenge for PE teachers, being perceived as one of the biggest problems. In addition, it indicates that there are strategies that teachers can use to reduce inappropriate behaviors in a way that improves the classroom climate and learning.

On the other hand, Viciana (2001) ${ }^{[20]}$ indicates that planning is a necessary process for the design and achievement of products in physical education, one of these products being the objectives aimed at the acquisition of habits, attitudes and positive values with the environment and with people. We could include this conception within Education for Peace, but we could include more specifically, in planning, the objectives aimed at reducing the number of behaviors contrary to coexistence during class.

Moreno et al. (2007), citing Sáenz-López (1997), indicate that "the direction of the class encompasses numerous aspects, one of the most relevant being the one that refers to organization and discipline, since without it they will not be able to To carry out the proposed objectives, the classes will be disorderly and the greater time will be subject to the "fight" against the students". In this sense, when talking about classroom control, reference is made to a wide range of behaviors on the part of the teacher, the most critical being the control of the behavior of the students And along the same lines Friedmann (1983), cited by Gutiérrez and Pilsa (2006) ${ }^{[17]}$, highlight that the students, with respect to PE teachers, valued very positively the professional competence, sportsmanship, pleasant appearance and self-confidence of their teachers, and as negative characteristics they highlighted the lack of objectivity in the qualifications and the favoritism towards some students.

\section{Conclusions}

The use of conflict resolution techniques by physical education teachers and educational centers could help improve the atmosphere of coexistence and reduce the number of conflictive incidents. It is necessary to improve the initial and continuous training of teachers in school mediation. 


\section{Acknowledgements}

This research has been funded by the Educational Research Project with reference PIV-069/08 (Junta de Andalucía, Spain). Thank the support and involvement of the Thesis Directors related to this research and project, Miguel Ángel Delgado-Noguera y Palma Chillón.

\section{References}

1. Bardisa T. El Complejo puzzle de la enseñanza secundaria. Curso de Experto Universitario en Convivencia Escolar. UNED. Bloque temático II. Tema 2007a;1.

2. Bardisa T. Los actores de los centros de secundaria. Curso de Experto Universitario en Convivencia Escolar. UNED. Bloque temático II. Tema 2007b;2.

3. Estévez E. Violencia, victimización y rechazo escolar en la adolescencia. Tesis doctoral. Universidad de Valencia 2005.

4. Fernández I. Prevención de la Violencia y Resolución de Conflictos. El clima escolar como factor de calidad. Edo Narcea. Madrid 2007.

5. Fernández-Balboa JM. Beliefs, Interactive Thoughts, and Actions of Physical Education Student Teachers Regarding Pupil Misbehaviors. Journal of Teaching in Physical Education 1991;11:59-78.

6. García RJ. Innovación, cultura y poder en las instituciones educativas. La complejidad en el cambio de Educación. Educar 2005;35:11-27.

7. García RJ. La promoción de la Convivencia en las instituciones educativas: Investigaciones recientes. Curso de Experto Universitario en Convivencia Escolar. UNED. Bloque Temático II. Tema 2007;3.

8. Jares $\mathrm{X}$. Conflicto y Convivencia en los centros educativos de secundaria. Revista de Educación 2006;339:467-491.

9. Little TD, Henrich C, Jones S, Hawley P. Disentangling the "whys" from the "whats" of aggressive behaviour. International Journal of Behavioral Development 2003b;27(2):122-133.

10. Martínez-Otero V. Convivencia escolar: problemas y soluciones. Revista Complutense de Educación 2001;12(1):295-318.

11. Moliner OY, Martí M. Estrategias didácticas para la solución cooperativa de conflictos y toma de decisiones consensuadas: mejorar la Convivencia en el aula. Revista Electrónica Interuniversitaria de Formación del Profesorado. Consultado el 28 de abril de 2009;5(3). http://www.aufop.com/aufop/revistas/lista/digital

12. Ortega Violencia R, Agresión Disciplina $\mathrm{Y}$, En Fernández. Prevención de la Violencia y Resolución de Conflictos. El clima escolar como factor de calidad. Narcea. Madrid 2007, P19-31.

13. Palomero JEY, Fernández $M^{a} R$. La formación del profesorado ante el fenómeno de la violencia $y$ Convivencia escolar. Revista Interuniversitaria de Formación del Profesorado, Consultada el 20 de abril de 2009;44:15-35.

http://dialnet.unirioja.es/servlet/articulo?codigo $=249627$

14. Prat MY, Soler S. Las posibilidades del juego, la actividad Física y el deporte para la mejora de la Convivencia. Revista Electrónica Interuniversitaria de Formación del Profesorado. Consultada el 27 de abril de 2009 ,

$5(2)$. http://www.aufop.com/aufop/revistas/lista/digital

15. Rajadell N. La importancia de las estrategias docentes para la resolución de conflictos en el aula. Revista Electrónica Interuniversitaria de Formación del Profesorado. Consultada el 27 de abril de 2009;5(3). http://www.aufop.com/aufop/revistas/lista/digital

16. Rincón B. Variables que sustentan la Convivencia en los centros educativos. Revista electrónica Interuniversitaria de Formación del Profesorado. Consultada el 27 de abril de 2009;5 (1).

http://www.aufop.com/aufop/revistas/lista/digital

17. Rodríguez FJ, Gutiérrez C, Herrero FJ, Albuerne F, Cuesta M, Hernández E, Gómez P, Jiménez A. Violencia en la enseñanza obligatoria: Alternativas desde la perspectiva del profesorado. Revista electrónica de Metodología Aplicada 2004;9(1):12-27.

18. Solana AM. La utilización de los Estilos de Enseñanza en el ámbito del deporte escolar: Posibilidades para incrementar la implicación del alumno/jugador en su propio aprendizaje. Habilidad Motriz 2005;25:18-24.

19. Solana AM. La participación de los alumnos en las clases de Educación Física: una perspectiva cualitativa de sus comportamientos. Revista Digital - Buenos Aires Año 9. Consultado el 10 de septiembre de 2008;67. http://www.efdeportes.com/efd67/particip.htm

20. Viciana J. El proceso de la planificación educativa en Educación Física. La jerarquización vertical y horizontal como principios de su diseño. Lecturas EF y Deportes, Año 6. Consultado el 21 de noviembre de 2007;32:1-3. http://www.efdeportes.com/efd32/planif.htm

21. Wuest D. Establishing and Maintaining Appropriate Behavior in PE Classes. PE Central. Consultado el 14 de julio de 2009.

http://www.pecentral.org/climate/october98article.html. 